\title{
A Geostrategic and Geo-economic Study of China-Bangladesh Relations Regarding the Bay of Bengal and Indian Ocean
}

Akkas Ahamed ${ }^{1} \&$ Md. Sayedur Rahman*2

${ }^{1}$ Associate Professor, Department of Political Science, University of Chittagong, Chittagong-4331, Bangladesh

${ }^{2}$ Assistant Professor, Department of Political Science, Faculty of Social Sciences, Begum Rokeya University, Rangpur-5400, Bangladesh \& Masters Student, Master's Programme in Socioeconomic and Political Development of Modern Asia, Faculty of World Economy and International Affairs, National Research University Higher School of Economics, Moscow, Russian Federation

$\begin{array}{ll}\begin{array}{l}\text { Article History } \\ \text { Received: } 24.08 .2020\end{array} & \begin{array}{l}\text { Abstract: Geo-strategy, a subfield of geopolitics, is a type of foreign policy guided } \\ \text { principally by geographical factors as they inform, constrain, or affect political and } \\ \text { Published: } 30.092020\end{array} \\ \text { military planning. The Bay of Bengal is very rich in natural resources. The Bay is very } \\ \text { substantial for China and India, for the imports of oil from the Middle East and African } \\ \text { countries. The geopolitics of the increasingly volatile South China Sea could possibly } \\ \text { impact on India's interests and relations with Southeast Asian countries. This paper } \\ \text { https://www.easpublisher.com/easjebm } \\ \text { examines whether China and India's Indian Ocean strategies underpin greater } \\ \text { cooperation, rather than competition to generate synergies in the region. The main } \\ \text { objective of this study is to focus on the geo-strategic and geo-economic importance of } \\ \text { the Bay of Bengal and Indian Ocean where China has huge interest. Moreover, the study } \\ \text { has found that the Bay of Bengal, and South East Bangladesh, is very important for } \\ \text { China, for trade and investments and exports and imports purposes. This study has been } \\ \text { carried out on the basis of focus group discussions, observation, and secondary data. } \\ \text { Keywords: Geostrategic, Geo-economic, China, Bangladesh, Bay of Bengal, Indian } \\ \text { Ocean, Regional Connectivity, Oil and Gas, Seaports, Exports and Imports. }\end{array}$

Copyright @ 2020: This is an open-access article distributed under the terms of the Creative Commons Attribution license which permits unrestricted use, distribution, and reproduction in any medium for non-commercial use (Non-Commercial or CC-BY-NC) provided the original author and source are credited.

\section{INTRODUCTION}

The Bay of Bengal is an important hub of economic activities connecting South, Southeast, and East Asia. Growing economic importance has made the region an increasingly important center of global focus (Kaplan, 2009; Islam, 2013). Their mutual threat perception is especially acute in the region; both countries are suspicious about the strategies initiated by each other. China is constructing infrastructural establishments, such as regional connectivity projects, for economic and strategic interests. On the contrary, India is also developing its own infrastructure, projecting connectivity initiatives, and establishing its own sub-regional development cooperation for economic, defense, and strategic relations with the Bay of Bengal and Indian Ocean countries (Brewster, 2014; Islam, 2013).

Das (2011) has explained on the need of development of armed infrastructures in the Andaman and Nicobar Islands, and how these may provide India with protected position in the Bay of Bengal and Indian Ocean. The paper will, thus, explore the nature of the strategic competition of the two countries in the Bay of Bengal region, and will determine the reasons for regional cooperation (Das, 2011 \& Islam, 2013). Most importantly, the study has examined the interests of China in the Bay of Bengal and Indian Ocean. Also Bangladesh is an integral part of China, for long term goal of regional connectivity, and trade and investment in the region. Also the study has examined the China's geo-economic interests in the Bay of Bengal and Indian Ocean. It has further stressed on the safe navigation of exports and imports, and exploration of oil and gas in the Bay of Bengal and Indian Ocean.

\section{China-Bangladesh Geo-strategic Relations}

From China's economic and strategic point of view, Bangladesh may be of less importance. But it cannot ignore the Bangladesh's Bay of Bengal as its economic and commercial passage (Noor). Considering the geostrategic importance of Bangladesh, China has proposed to construct a deep sea port on the Sonadia Island in the Bay of Bengal. But the project has not yet been come into effect due to India's objection. Now Japan has come ahead with a new proposal of construction of a deep sea port in Matarbari, Mohesh Khali sub-district of Cox's Bazar (Noor, 2020).

At this moment, China is concentrating on bombarding seabed oil and gas from the Myanmar 
deep-sea blocks. China's aim is to conquer the region considering these two distinct points:

1) The "string of pearls" concept that stresses on the military and economic advantages through some marine passages such as Strait of Malacca, Lombok Strait, Strait of Hormuz, and countries such as Bangladesh, the Maldives and Pakistan (Noor, 2020).

2) The 21 st Century Maritime Silk Route that connects the Silk Road Economic Belt of the Chinese Belt and Road Initiative (BRI) with a common objective of connecting China's landlocked southern provinces to the Indian Ocean. By building the "pearl," China could have an easy access to the Bay of Bengal, for it's the navigation of its submarines and military points and exercise. This can eventually balance the prevailing marine viewpoint in the northern Indian Ocean at Coco Island which could strictly confine the regional power of the Indian Naval activities. The Maritime Silk Route could offer momentous opportunities for economic and trading activities under the Belt and Road Initiative of China (Noor, 2020).

In the context of multi-modal transport development, the China- Bangladesh-Myanmar trinational highway stretches from Cox's Bazar's Balukhali-Gundhum border road to Kunming, capital city of Yunnan in China. The Asian Highway and Bangladesh, China, India, and Myanmar (BCIM) can promote economic activities within these countries (Noor, 2020). Unintentionally, China's existence paved incitement for US military presence in the region. To combat against this non-regional armed presences, NSA, India has indicated of founding a marine security alliance in the Bay, Bangladesh as one of the two considered partners (Noor, 2020). But, many scholars think that Bangladesh should not agree with the offer of India's military alliance against China. China is an important country for Bangladesh's socio-economic and infrastructural development.

\section{China-Bangladesh Strategic and Military Relations}

Bangladesh is the second biggest importer of Chinese arms after Pakistan. Bangladesh-China relations are to China's advantage. As of 2019, Bangladesh's bilateral trade deficit with China had increased 1600 percent in the last 20 years, even as 25 percent of Bangladesh's total imports were from China. China has given financial assistance and loans to Bangladesh on less interest than the loans provided by India. And China has offered to construct nuclear power plants in Bangladesh, which is very important for Bangladesh, to meet energy demand. From July 1, 2020, China has relinquished charges of 97 percent goods made in Bangladesh (Katoch, 2020).

It is true that the It is the Awami League government of Bangladesh under the leadership of Prime Minister Sheikh Hasina has taken serious actions on terrorism and religious dogmatism and has cooperated with India vigorously on the issue. And the
Awami League government has handed over many alleged extremists to India when requested by India. But, on the other hand, the earlier Bangladesh Nationalist Party (BNP) government under the leadership of Khalida Zia was conducting anti-India extremist camps in Bangladesh's territory whereas the then Bangladesh Armed forces were practicing their own type of 'cold start' into Indian terrain to be continued for the first few days by insurgent-cumradical organizations in the slight land strip connecting India's Northeast India. These terrorist camps had trainers from Al Qaeda, Lashkar-e-Taiba (LeT) and Pakistan's Inter-Services Intelligence (ISI) (Katoch, 2020).

However, in terms of Bangladesh's strategic and military relationship with both India and China, many scholars think that building a strategic and military relationship with China is far better than India. China does not have direct land border, and territorial disputes with Bangladesh. But Bangladesh has territorial and maritime boundary disputes with India. Therefore, Bangladesh's military relationship with China is safer compared to India.

\section{Geo-strategic Interests of China in the Bay of Bengal}

The Bay of Bengal is now considered as one of the geo-political epicenters in the Bay of Bengal and Indian Ocean regions. It is now used as important trading routes, and military and strategic points. Being the host of the Bay of Bengal, Bangladesh is in the most advantageous position to harness the jostling and maneuver to its economic and strategic gain. If Dhaka is interested to take advantage of this, it can easily enjoy (Noor. 2020).

\section{China's Naval Presence in the Bay of Bengal and Indian Ocean}

Some observers have also raised questions on the China's naval presence in the Bay of Bengal and Indian Ocean. They think that construction of a deep sea port can be used by the China's naval force for military and strategic purposes in the Bay of Bengal and Indian Ocean against Indian presence in the region. Considering the India's pressure, Bangladesh is now trying to attract foreign investors to build a deep sea port in Cox's Bazar instead of China (Brewster, 2014).

However, Sri Lanka is now being considered as a potential strategic partner by China, and there has been huge investment by the Chinese companies. Colombo is very interested in attracting the Chinese investment, for socio-economic and infrastructural development in the country. Sri Lanka is also one of the important partners of China's Maritime Silk Road (MRS) initiative (Brewster, 2014).

Sri Lanka is also providing China with military access to the region. In October 2014, it was declared that Chinese government has been requested to take 
over controlling of a new and enlarged Phase II development of Hambantota port, and the port can be absolutely used by the Chinese government. The Sri Lankan government has also proposed to train up and build up a military base in Northern Sri Lanka so as to support the Sri Lankan military and Air Force. Many Indian scholars and observers think that Chinese armed presence in Sri Lanka have been intensified by the visits in September and October in 2014 of Chinese submarines to a new port in Colombo, which has been built by China. At the initial stage, the Sri Lankan government was reluctant to expose the Chinese military presence in the Indian Ocean, but now it intends to maintain strategic relations with China through the military presence of China in the Indian Ocean (Brewster, 2014). It is also true that India's hegemonic foreign policy towards the South Asia and Bay of Bengal countries is mostly liable for the China's military presence in the Bay of Bengal and Indian Ocean.

Such a military presence in the region would have an important impact on security dynamics in the Bay of Bengal and Indian Ocean. Sri Lanka, geostrategically situated in the central Indian Ocean. Surely, China's increasing security relations with Sri Lanka creates some doubts on China's announcement that the Maritime Silk Road (MSR) is simply an economic project (Brewster, 2014). Therefore, it may be said that China has two strategies in the Bay of Bengal and Indian Ocean: military and economic. Also the countries of the Bay of Bengal might have a chance to promote their economies on the assistance and support of China's gigantic economy of US \$30 trillion, by purchasing power parity (PPP), which is the largest economy in the world by purchasing power parity. India is lagging behind far way compared to China in the context economic capacity and foreign currency reserves. Thus the small countries of South Asia and Bay of Bengal should come ahead to maintain friendly relations with China to have an access to the Chinese development cooperation and Chinese foreign investment.

\section{Developing China's Indian Ocean Strategy}

From the strategic perspective, the Indian Ocean is very important to China's trade and investment, and energy security. China has faced with a huge problem in the Malacca Strait for years, due to the geo-strategic stress from India and the United States and. China has taken a plan of constructing the " 21 st Century Maritime Silk Road," and China wants to develop an Indian Ocean strategy based on security for all member states, which must be free of any threat from any other country. China has a plan to build an Indian Ocean fleet, and it wants to share power quietly with the United States and India, so as to defend its real rights and politico-economic interests in the region (Kaplan, 2009; Jiacheng, 2017).
After the collapse of the Soviet Union, The United States of America has enjoyed a huge hegemonic power all over the world. But, in recent years, its politico-economic power has been weakened in large part by its regular practice of armed forces in the Middle Eastern countries and other countries of the world. In the meantime, China has appeared as the world's second largest economic power by nominal GDP, and the largest economy by the GDP of purchasing power parity. The economic and military rise of China and the weakening of U.S. impact are composed to make changes in the remaining power structure in the Pacific and Indian Ocean regions including the Bay of Bengal. Thus, China desires to grasp every opportunity to formulate a long-term strategic decision for Indian Ocean strategy, so as to ensure regional peace and security as well as the openness of sea routes.

The Indian Ocean, which is the third largest ocean in the world, splitting Asia, Antarctica, Africa, and Oceania, covers a total area of 73.44 million square kilometers. To the north of the Indian Ocean are India, Pakistan and Iran; to the west is the Arabian Peninsula and Africa, and to the east are Australia, the Malay Peninsula and Indonesia. The Indian Ocean is the strategic junction of the Pacific Ocean, the Atlantic Ocean and the Mediterranean Sea. It has, undoubtedly, become the central route of communication between Asia, Europe, Africa and Oceania (Kaplan, 2009; Jiacheng, 2017). The northern site of the Indian Ocean constitutes the Eurasia that covers several battle zones, and it is also recognized as an "arc of Islam." In the history, any political power that controlled the edge of the Eurasian region alongside the northern portion of the Indian Ocean could control the entire Indian Ocean, and, could easily enter into the "hub" of Eurasia (Dexing 2009; Jiacheng , 2017). Therefore, the Indian Ocean is the strategic region for global powers competition. Since the end of World War two, it is the world's busiest international channel, which is known as "the Gibraltar of the east," and it supports around a quarter of the world's marine trade. Currently, over 50,000 vessels pass through this Strait each year, of those almost 60 percent are Chinese containers (Qi-min, 2009, Jiacheng, 2017).

China's oil imports depend on heavily on the Strait of Malacca; such as any impasse in the Strait would be a severe risk to China's energy security. This is the source of the "Malacca Problem" for China over the past few eras. In 2009, China has turned into the world's third largest oil importer, accounting for 7.5 percent of global total oil trade. In the same year, China has become the world's largest oil consumer, accounting for 9.3 percent of global consumption (BP Statistical Review of World Energy, 2015; Jiacheng, 2017). Presently, more than half of China's internal oil imports come from the Middle Eastern countries, Africa, and Southeast Asia, and about four-fifths of the 
imported crude oil is transported through the Malacca Strait. China's three largest oil exporters are Angola, Iran, and Saudi Arabia. Such weighty dependence on the shipping canal postures a potential threat to China's energy security, which is topic to the shifting dynamics of strategic competition amongst major powers over control of the Malacca Strait (Lanteigne, 2008; Jiacheng, 2017).

India's establishment of marine power in the Indian Ocean and the Bay of Bengal, and its "Look East" policy, as well as the long-lasting presence of American military forces has an impact in the region. An American researcher at the National Defense University, has suggested, if China is involved with the United States in an armed conflict, the latter might implement the plan of "sea control," barrier the Strait of Malacca, which interrupt all the exports and imports activities in and out of these waters, and force China to withdraw. According to him, the United States can send 13 to 15 marine corps units to interrupt about 800 vessels carrying or exporting goods and chattels to China's main ports which are located in South China, Hainan, Hong Kong, Macao, Shanghai, Guangzhou, and other ports located in the East coast of China (Jiacheng, 2017).

Therefore, China is obviously aware of this possible circumstance, and so has begun to diminish its susceptibility by constructing transport networks and deep sea ports in Sri Lanka, Pakistan and Myanmar. China's western province and southern provinces have now been connected with the ports of Pakistan and Myanmar, through the land roads connectivity of these two countries. But, on political and strategic reasons, trade routes and energy supplies in the Indian Ocean, in precise through the Malacca Strait, continue to be crucial to China. As the Indian Ocean route is the utmost important of China's four major shipment routes (the other three are: East Pacific, the Arctic and the Atlantic, respectively), accounting for 40 percent of China's overseas trade, and 80 percent of its total imports, it is usual for the Chinese government to consider the Indian Ocean and the Malacca Strait as a main sea zones of the 21st Century Maritime Silk Road. For safety of the Maritime Silk Road, China wants to increase its presence in the Indian Ocean, and it has to ensure the interconnectivity between the Indian Ocean and the Pacific while avoiding the "Malacca Dilemma," so as to guarantee safety and free passage in the Indian Ocean (Jiacheng, 2017).

\section{China-Bangladesh Economic and Strategic Partnership}

In facilitating bilateral economic and security relations, the two countries, China and Bangladesh, have signed a good number of agreements and memoranda that include trade, uses of seaports in Bangladesh, and power plants (Kashem, 2016 \& Islam, 2013). Similar to China, India and Bangladesh also have signed an agreement on sharing intelligence to prevent terrorism and religious extremism (The New Age, April 10, 2017). Bangladesh has also provided India with naval and land corridors for transporting their goods from the mainland to its northeastern region. India has already started to transport their goods to the region through the land and river routes of Bangladesh. Moreover, during Bangladesh's Prime Minister, Sheikh Hasina's visit to India on 7-10 April, 2017, Bangladesh and India signed six agreements and 16 memoranda of understanding which include cooperation on nuclear power, border trade, cooperation in the field of information technology and electronics, cooperation in outer space research and strategic studies, cyber security, etc (The Daily Star, April 09, 2017). Significantly, a major aspect of the visit has been defense cooperation which includes a memorandum of understanding on a defense framework, and a $\$ 500$ million line of credit for defense procurement for the Bangladesh's military forces (Islam, 2013).

Despite the pressure from India, and the Indian criticism of Chinese President Xi Jinping's visit to Bangladesh in October 2016, several agreements were nonetheless signed between China and Bangladesh. Bangladesh's newspapers reported that the government was under tremendous diplomatic pressure from India, especially after they received four submarines for the Bangladesh's Navy from China. Consequently, Bangladesh has signed a MoU on defense frameworks in order to balance its relations with China and India. It can, therefore, be noted that India has tried to influence domestic politics and international affairs of Bangladesh in order to exclude Chinese influence on the country (Islam, 2013). Also many Bangladesh's scholars think that Bangladesh should come ahead to maintain friendly relations with China for the greater economic interests and territorial security and sovereignty of the country, against the continuous border threat posed by the Indian security forces.

\section{Connectivity Initiatives of China and China- Bangladesh Geo-strategic Geo-economic Relations}

Most importantly, in the Bay region there are already Chinese industrial parks in Myanmar, Thailand, Malaysia, Indonesia, Sri Lanka, and Bangladesh. The overland and maritime connectivity projects and engagement with the littoral countries of the Bay will work as a response to the changing geopolitical situation marked by the US as a rebalance to Asia, and erase China's historic vulnerability to India in the Bay of Bengal region. This will allow Beijing to ensure its security there. As for mutual cooperation and mutual development, the economic corridors and the maritime Silk Road' may enable the creation of a growth triangle of these countries and will facilitate China's Western Development Strategy. For a long time, the communication system and infrastructure of the region have been weak, and the economy developed slowly since the region is landlocked and far from the center of 
growth in China (Fan, 2011). China will be able to transport energy and goods to and from its southwestern region easily, on time, and at a minimum transport cost. These would bind the Bay of Bengal much closer to the Chinese economy. Moreover, Beijing has been successful in developing connections through Myanmar, including the recently completed oil and gas pipelines between the new deep seaport of Kyaukpyu in Myanmar and its Yunnan province. The natural gas pipeline project started to transport gas to China on July 282013 (Liu, 2013).

The 2,806 km long gas pipeline runs from Ruili to Kunming and reaches southwestern provinces such as Guizhou and Guangxi (Liu, 2013). The Kyaukpyu project was also included in the $1200 \mathrm{~km}$ railway and highway at the cost of $\$ 20$ billion (Kostecka, D.J., 2010). The new Sino-Myanmar pipelines, railway and highway Kyaukpyu projects can reduce China's reliance on the Straits of Malacca and diversify China's oil and gas supply. It will lessen risks and strengthen China's ability to cope with the complex and volatile international situation New Delhi fears that Beijing's connectivity initiatives will challenge India's interests in the region and that the proposed BCIM Economic Corridor could even threaten India's national cohesion by integrating India's estranged northeastern states into the Chinese economy (Uberoi, 2016).

India, by contrast, promotes the Trilateral Highway Project that would build road connections from Delhi to Thailand via Bangladesh, India's northeastern states, and Myanmar. At the meeting among representatives of India, Myanmar, and Thailand in Naypyidaw in April 2012, the three countries formally agreed on the construction of an India-MyanmarThailand trilateral highway (The Economic Times, October 22, 2013). The project aims to connect the three countries through the construction of a highway from Moreh in Manipur state via Mandalay and Yangon in Myanmar to Mae Sot in Thailand. While the project was announced in late 2013, recent projections estimate its completion by 2016 (The Hindu, May 30, 2013). But in summer 2014, several newspapers reported that 2017 may be a more realistic timeframe for completion (The Hindustan Times, June 24, 2014).

However, it was unclear about the progress towards constructing the trilateral highway project between the three countries. New Delhi's overland connection project with Southeast Asia through the Bay of Bengal region is challenging to build due to the impoverished condition of its eastern neighbors, ethnic insurgencies and political problems over transit rights. It will, however, enhance India's focus on balancing its interests to protect its strategic position in the region. India is also sponsoring the renewal of shipping connections across the Bay of Bengal. Until the 1940s, Calcutta was the hub for a dense intraregional shipping network connecting India and the territories around the
Bay, and linking rivers such as the Ganges, Brahmaputra, and Irrawaddy to provide direct connections with more remote areas. These connections withered away in the decades following the independence of India, Pakistan, and Myanmar from the colonial rule. Following the demarcation of borders of these sovereign states, and a lack of agreement among them on the shipping route made barriers continue. However, India is reviving the old oceanic and river shipping routes as they are much more simple and costeffective for intra-regional connection. In October 2014, the Indian state-owned shipping line restarted direct connections between Chennai, Colombo and Rangoon, initiating connections between ports in India and Bangladesh on a trial basis. India has long been transporting goods and energy to its northeastern region through the river routes of Bangladesh. It has also developed the Kaladan multimodal transport projects with Myanmar. The project will link the ports of Kolkata (India) and Sittwe (Myanmar) by shipping route, and link Sittwe with Lashio further up to the Kaladan River by boat (Indian Express, June 17, 2006).

A road will then link Lashio with the Mizoram province of India. An agreement was signed between the two countries in 2008 to implement the project (Htun, 2011 \& Islam, 2013). The main rationale has been to improve connectivity between mainland India and the northeastern states by creating an alternative to the Siliguri corridor which is at present the only route. India is also keen for its companies to participate in the proposed new port project near Chittagong in Bangladesh that would help to connect its northeastern Tripura state via road and allow it to transport goods to the region at minimum cost and time (Htun, 2011 \& Islam 2013). The Indian connectivity initiative will provide access to Southeast Asia and the greater Mekong region, while also reducing China's influence in the region.

\section{Sub-regional Cooperation in the Context of Bay of Bengal}

The Bay of Bengal Initiative for Multi-Sectoral Technical and Economic Cooperation (BIMSTEC) comprising Bangladesh, Bhutan, India, Myanmar, Nepal, Thailand, and Sri Lanka is a viable option for India to form an effective regional group to promote broader economic and strategic integration. Its objective is to create an environment that enables rapid economic development, accelerates social progress, and maintains close and beneficial cooperation with the existing international and regional organizations (Sharma \& Rathore, 2015 \& Islam, 2013).

BIMSTEC can act as a bridge between South Asia and Southeast Asia, and the signing of the framework agreement for this free trade area in 2004 was a major step forward in its creation. In signing the agreement, India acquired an opportunity to revive its past relations with its old colonial-era partners. The 
BIMSTEC framework agreement was initiated as part of the Indian "Look East" policy, and India is a leading member of the organization. Recently, New Delhi has renewed its focus on the BIMSTEC grouping due to the need to develop improved transport connectivity across the Bay of Bengal. Indian Prime Minister, Manmohan Singh stated at the BIMSTEC summit held in Myanmar in March 2014 that: "Connectivity: physical and digital, is the key to (BIMSTEC's) vision and can be a driver of cooperation and integration in our region (Brewster, 2014 \& Islam, 2013). BIMSTEC may contribute to enhance India's focus on balancing its interests to protect its strategic position and reduce Chinese influence in the region. Moreover, India's sub-regional cooperation across the Bay of Bengal has been accompanied by an expansion of its primary area of strategic interest. India has long aspired to be recognized as the predominant power in the Bay of Bengal and it now also aspires to assume a greater strategic role in Southeast Asian and the Pacific countries. The idea of the Indo-Pacific has emerged on the basis of strategic space of the Bay of Bengal. The idea is being promoted by strategic thinkers and political leaders in the United States, Japan, India, and Australia (Nautiyal, 2017 \& Islam, 2013).

The US especially is encouraging an expansion of India's security role eastwards into Southeast Asia and the Pacific, largely driven by concerns about China (Nautiyal, 2017). India is now going to make IndoPacific cooperation, a goal in order to form an antiChina coalition of maritime power which may include nations such as the US, Japan, India, and Australia, although at this point it does not have any organizational structure. China has, in contrast, promoted sub-regional cooperation to make collective effort in the development of infrastructure, fostered economic development, and minimized its geographical vulnerability. Significantly, Beijing initiated the BCIM forum for sub-regional cooperation as the Kunming Initiative in August 1999, comprising Bangladesh, Southwestern China, Northeastern India, and Myanmar. The forum has become an important sub-regional cooperation mechanism in the region, aiming at greater infrastructural development, building connectivity and enhancing economic integration. It will link the Bay of Bengal with northeastern India and Southwestern China, and promote contact among these four countries at both the public and private sector level. Likewise, the Greater Mekong sub-region, started in 1992, has incorporated the six littoral countries of the Bay of Bengal consisting of Cambodia, Laos, Myanmar, Thailand, Vietnam, and Yunnan and Guangxi provinces of China. The countries of the Greater Mekong region emphasized interregional connectivity and 'regional integration' rather than competitiveness and community (Das, 2013).

The transport links established within the region, for example, the North-South Corridor, and
East-West Corridor, link different parts of Vietnam to Laos, Cambodia, Thailand, and Myanmar, and Yunnan and Gaungxi province of China. The sub-regional zones are, therefore, the meeting point of the three markets of China, Southeast, and South Asia. There are abundant natural resources, labor and established international sea routes. Some Indian experts argue that the subregional cooperation zones will be a growing assertion of Chinese economic-cum-political power. It will facilitate China's ability to make explicit alignment by the countries with its "neighborhood", in particular, the coastal countries of the Bay of Bengal. Moreover, it will contribute to balancing China's strategic position with India and other rival powers to protect its interests in the region.

\section{CONCLUSION}

Most importantly, China is developing links from its Southwestern region to the Bay of Bengal in order to open up the region as part of its Western Development Strategy. Similarly, India is trying to implement its "Look East" policy through the Bay of Bengal region to Southeast Asia. Both China and India are seeking to maximize their economic and strategic interests. China and India are developing economic, defense, and strategic partnerships with Bangladesh, Myanmar, and Sri Lanka. China is also constructing land routes, railway, gas and oil pipelines, seaports, and airfields in Myanmar in order to secure its connection to the Bay. It has also developed economic, strategic, and defense relations with Bangladesh and Sri Lanka, and is constructing highways, railways, and bridges, establishing Special Economic Zones, providing military hardware to the countries of Bay of Bay of Bengal, and developing seaports in Cox's Bazar (Bangladesh) and Hambantota (Sri Lanka).

India has also developed bilateral defense, economic, and strategic relationships with some of the littoral countries of the Bay of Bengal and is strengthening close relations with Myanmar in security and counterterrorism, trade and investment, infrastructure, and energy. It has built strong relationship with its immediate neighbors, Bangladesh and Sri Lanka, by signing several economic and defense agreements. In addition, both China and India have initiated sub-regional cooperation and connectivity initiatives to protect economic and strategic interests and to minimize security vulnerability in the Bay region. China's proposed BCIM and Indo-China economic corridors could provide the land-locked western region of China an access to the Bay and stimulate sub-regional economic development. Moreover, the Maritime Silk Road will touch the major sea ports of littoral countries of the Bay (Islam, 2013).

There is no evidence that China interferes in internal politics of these countries. However, China has encouraged the littoral countries to follow an independent foreign policy and move away from India's 
sphere of influence (Islam, 2013). Moreover, China's economic engagement and strategic partnership with the coastal countries is stronger than Indian engagement and strategic relations. Further, China's connectivity initiatives are more acceptable and the country is successful in completing oil and gas pipelines to link its southwestern region to the Bay through Myanmar. Therefore, considering the success of connectivity initiatives and sub-regional cooperation, the depth of economic engagement, and the strategic partnership of China with the coastal countries of the Bay is playing a crucial role in the region. The Bay of Bengal is vital for a geostrategic balance between the two powers.

To sum up, China's large-scale involvement in the Indian Ocean will quietly reconstruct the power relationship of the region. With the new initiative of the "21st Century Maritime Silk Road," China is seeking more security presence in the region with growing political, economic and military influence, in order to safeguard its legitimate rights and interests. The Indian Ocean should not be regarded as India's "sphere of influence," although India's special concern and interests should by all means be respected. In fact, China, the United States, India and other naval powers should try to reach an agreement similar to the Montreux Convention Regarding the Regime of the Straits in 1936, which allows each party to protect the legitimate rights and interests of their own without harming those of other parties, so as to achieve peace and neutralization of all open seas in the Indian Ocean (Jiacheng, 2017).

However, in a nutshell, it can be said that Bangladesh's geostrategic position is important for China. Bay of Bengal, which is connected with the Indian Ocean, has originated from Bangladesh. Cox's Bazar is very close to China geographically. Therefore, friendly relationship between the two countries, in terms of trade and investment, regional connectivity, Bay of Bengal, Indian Ocean and exploration and production of oil and gas, are very significant. So, China and Bangladesh should come ahead to strengthen the existing relationship for the greater interests of two countries.

\section{Acknowledgment}

We hereby acknowledge the input of every member of this team for their tireless efforts during this work.

\section{REFERENCES}

1. BP Statistical Review of World Energy, (2015). http://www.bp.com/content/dam/bp/pdf/ Energyeconomics/statistical-review-2015/bp-statisticalreview-of-world-energy-2015-fullreport.pdf.

2. Brewster, D. (2014). "Dividing Lines: Evolving Mental Maps of the Bay of Bengal," Asian Security 10, no.2:151-67.
3. Brewster, D. (December 14, 2014), The Bay of Bengal: The Maritime Silk Route and China's Naval Ambitions, With its Maritime Silk Route initiative, China is rapidly developing a presence in the Bay of Bengal, The Strategist

4. Das, G., Paul, U.K. \& Mathur, T. (2013). "Subregional Cooperation for the Development of Landlocked Peripheral Areas: The Case of BCIM," South Asian Survey 20, no. 1: 74-93.

5. Das, P. (May 2011). "Securing the Andaman and Nicobar Islands," Strategic Analysis 35, no. 1: 465 78.

6. Dexing, S. \& Jun, B. (2009). "21shiji zhi yang: diyuanzhanlue shijiaoxia de yinduyang [Ocean of the Twenty-first Century: The Indian Ocean from a Geostrategic Perspective]," South Asia Research, No. 3, p. 35.

7. Fan, H. (2011). “China's 'Look South': ChinaMyanmar Transport Corridor," Ritsumeikan International Affairs 10: 43-66.

8. Htun, K. W., Lwin, N. N., Naing, T. H. \& Tun, K. (2011). "ASEAN-India Connectivity: A Myanmar Perspective" in ASEAN-India Connectivity: The Comprehensive Asia Development Plan, Phase II, ERIA Research Project Report 2010-7, eds., Kimura, F. and S. Umezaki (Jakarta: ERIA, 151203.

9. Indian Express, (June 17, 2006).

10. Islam, M. S. (2013). "Sino-Bangladesh Relations: Geo-strategic and Geo-political Implications," in Sino-South Asian Relations: Continuity and Change, ed., Md. Monoar Kabir (Chittagong, Bangladesh: Department of Political Science, University of Chittagong, 204.

11. Jiacheng, L. (2017), Developing China's Indian Ocean Strategy Rationale and Prospects China Quarterly of International Strategic Studies, Vol. 3, No. 4, 481-497

12. Kaplan, R, cited in Brewster, D. (April-June 2015)."The Rise of the Bengal Tigers: The Growing Strategic Importance of the Bay of Bengal," Journal of Defense Studies 9, no. 2: 89.

13. Kaplan, R. D. (March /April 2009). "Center Stage for the Twenty-first Century: Power Plays in the Indian Ocean," Foreign Affairs, Vol. 88, No. 2, pp. 16-32.

14. Kashem, M. A. \&Islam, M. S. (2016). "Narendra Modi's Bangladesh Policy and India-Bangladesh Relations: Challenges and Possible Policy Responses," India Quarterly 72, no.3:250-267.

15. Katoch, L. G. P. (Jul 25, 2020). China now has strategic interest in Bangladesh, Bangladesh is strategically important to China for dominating the Bay of Bengal in conjunction with Myanmar, South Asia Monitor

16. Kostecka, D.J. (2010). "The Chinese Navy's Emerging Support Network in the Indian Ocean," China Brief 10, no. 15:3-5.

17. Lanteigne, M. (2008). "China's Maritime Security and the "Malacca Dilemma," Asian Studies, Vol. 
4, No. 2, p. 144. There are some disputes whether Hu used this term, but it has certainly acquired a prominence due to its purported use by him.

18. Liu, (2013). "Sino-Myanmar Bilateral Relations in 2013," 176.

19. Nautiyal, A. (2017). "US Security Strategy of Asian Rebalance: India's Role and Concerns," Strategic Analysis 41, no. 1, 14-33.

20. Noor, R. (Jul 31, 2020). Bangladesh may be the new locus of Asian geo-strategy, The Dhaka Tribune, Friday,

21. Qi-min, W. (November 12, 2009). “Qingting lishide sushuo hujintaozhuxi fangwen maliujiahaixia ceji [Listening to History President $\mathrm{Hu}$ Jintao's visit to the Straits of Malacca]," People's

Daily,
http://cpc.people.com.cn/GB/64093/64094/103620

09.html

22. Sharma, A. \& Rathore, C. K. (2015). "BIMSTEC and BCIM Initiatives and their Importance for India," This Discussion Paper was researched and written for Centre for International Trade, Economics \& Environment (CUTS CITEE) D-217, 04, see at www.cuts-international.or

23. The Daily Star, April 09, 2017.

24. The Economic Times, (October 22, 2013).

25. The Hindu, (May 30, 2013).

26. The Hindustan Times, (June 24, 2014).

27. The New Age, (April 10, 2017).

28. Uberoi, P. (2016). "Problems and Prospects of BCIM Economic Corridor," China Report 52, no. 1:19-44. 